\title{
PENGEMBANGAN PROFESIONAL KEPERAWATAN BERHUBUNGAN DENGAN KEMAMPUAN PERAWAT DALAM MENGATASI NYERI PASIEN
}

\author{
Tri Mulia Herawati ${ }^{*}$, Rr. Tutik Sri Hariyati ${ }^{2}$, Efy Afifah ${ }^{2}$ \\ 1. PSIK Fakultas Kesehatan Universitas MH Thamrin, Jakarta 12720, Indonesia \\ 2. Fakultas Ilmu Keperawatan Universitas Indonesia, Depok 16424, Indonesia \\ *E-mail:tmherawati@gmail.com
}

\begin{abstract}
Abstrak
Pengembangan Profesional Berkelanjutan (PPB) merupakan komponen sistem jenjang karir dimana perencanaan dan implementasi perencanaan karir dapat memengaruhi proses kehidupan perawat. Jenjang karir di beberapa RS telah dilaksanakan namun kadangkala belum selaras dengan pelaksanaan rekrutmen, rotasi, pengembangan professional berkelanjutan dan promosi yang menjadi komponen tidak terpisah dari jenjang karir. Penelitian ini bertujuan mengidentifikasi pengaruh PPB dengan implementasi manajemen nyeri di rumah sakit. Disain penelitian menggunakan deskriptif korelasi dengan pendekatan cross sectional. Data dikumpulkan melalui data primer sebanyak 121 perawat pelaksana serta data sekunder dokumen rekam medis pasien berisi catatan keperawatan terkait manajemen nyeri yang terdiri dari pengkajian, intervensi dan re-evaluasi. Teknik pengambilan sampel adalah simple random sampling. Analisis menggunakan regresi linier berganda. Hasil penelitian didapatkan bahwa variabel implementasi sistem jenjang karir yang paling berpengaruh terhadap implementasi manajemen nyeri oleh perawat klinik adalah pengembangan profesional berkelanjutan $(\mathrm{PPB})(\mathrm{p}=0,027)$. Peneliti merekomendasikan perlunya perencanaan terstruktur melalui analisis kebutuhan training bagi masing-masing perawat
\end{abstract}

Kata kunci: sistem jenjang karir, perawat, pengembangan profesional berkelanjutan, manajemen nyeri

\begin{abstract}
The effect of continuous professional development to the implementation of pain managment by nurses in hospital. Continuing Professional Development (CPD) is a component of a career ladder system which its planning and implementation can affect in a nurse's life process. In some hospitals, the nursing career ladder system were not associated with recruitment, rotation, continuous professional development and promotion process. This study aimed to identify the effect of CPD to the implementation of pain management in a hospital. The design research was descriptive correlative with cross sectional approach. Data were collected through primary data as much as 121 nurses and also secondary data from patient medical records related to pain management nursing documentation included assessment, intervention, and re-evaluation. The sampling technique was simple random sampling. Data were analyzed by multiple linear regression. The result showed that the variables of the career ladder system implementation that most affected on the pain management implementation by clinical nurses is continuing professional development $(C P D)(p=0.027)$. It is recommended to make structured planning through training needs analysis for each nurse
\end{abstract}

Keywords: career ladder system, nurse, continuing professional development, pain management

\section{Pendahuluan}

Kualitas pelayanan keperawatan dapat dilihat dari pencapaian pelaksanaan indikator kualitas pelayanan keperawatan (Hariyati, 2014). National Quality Forum di tahun 2004 menetapkan 15 standar nasional yang digunakan untuk mengevaluasi pelayanan keperawatan. Indikator kualitas pelayanan keperawatan juga dapat merujuk pada data The National Database of Nursing Quality Indicator (Montalvo, 2007). Indonesia menetapkan 6 (enam) indikator mutu pelayanan klinik, salah satunya adalah terpenuhinya rasa nyaman (manajemen 
nyeri) (Direktorat Bina Pelayanan Keperawatan, 2008).

Pengelolaan nyeri pada pasien rumah sakit diberikan dalam bentuk proses manajemen nyeri komprehensif. Strategi optimalisasi manajemen nyeri dapat berfokus pada pendidikan staf, adanya prosedur pengkajian nyeri, batasan waktu pemberian obat, serta perbaikan proses pengkajian itu sendiri (Mantell, Hartwell, \& Branowicki, 2014). Praktisi kesehatan juga harus memiliki kemampuan atau kompetensi mengenai manajemen nyeri sesuai lingkup pelayanan yang diberikan dan perlu adanya pengembangan pengetahuan, keterampilan dalam melaksanakan manajemen nyeri. Pengembangan pengetahuan dan keterampilan dapat dilaksanakan dengan Pengembangan Profesionalisme Berkelanjutan (PPB) (Ozlu \& Uzun, 2015).

PPB merupakan bagian dari manajemen ketenagaan sebagai bagian dari pengembangan jenjang karir keperawatan yang mempunyai beberapa tahapan antara lain mapping karir, asesmen kompetensi, kredensial dan juga PPB. Beberapa rumah sakit sudah melaksanakan jenjang karir namun belum banyak hasil riset yang menyampaikan pengaruh implementasi jenjang karir terhadap kompetensi perawat dan mutu pelayanan keperawatan. Riset ini bertujuan untuk mengetahui hubungan pengembangan profesionalisme berkelanjutan sebagai bagian dari jenjang karir dan kompetensi perawat dalam melaksanakan manajemen nyeri.

\section{Metode}

Penelitian ini menggunakan pendekatan crosssectional, dilakukan di unit rawat inap, rumah sakit. Responden berjumlah 121 perawat di unit rawat inap dengan pengambilan sampel menggunakan tehnik simple random sampling.

Alat ukur yang digunakan adalah lembar observasi dokumen rekam medis untuk mengukur kemampuan dalam manajemen nyeri. Variabel independen penelitian yaitu imple- mentasi sistem jenjang pengukurannya menggunakan skala Guttman dengan skor 0 untuk jawaban tidak dan skor 1 untuk jawaban ya. Analisis data dalam penelitian ini menggunakan deskriptif dan uji regresi linear ganda dengan metode enter.

\section{Hasil}

Implementasi sistem jenjang karir di rumah sakit menunjukkan adanya hubungan bermakna dengan implementasi manajemen nyeri yaitu variabel pengembangan profesional berkelanjutan $(p=0,027)$. Karakteristik perawat klinik di unit rawat inap berdasarkan jenis kelamin yaitu sebagian besar perempuan (92, $6 \%$ ). Berdasarkan pendidikan terakhir sebagian besar berpendidikan D3 Keperawatan (90, $1 \%$ ) dan mayoritas sistem jenjang karir perawat klinik di unit rawat inap rumah sakit berada pada jenjang junior nurse yaitu sebanyak 83 orang $(68,6 \%)$ dengan rincian 80 orang $(66$, $12 \%)$ berpendidikan D3 Keperawatan dan 3 orang $(2,48 \%)$ berpendidikan S1 keperawatan.

Karakteristik berdasarkan umur menunjukkan bahwa nilai median umur perawat klinik adalah 27 tahun, dengan umur termuda adalah 21 tahun dan umur tertua 45 tahun. Mayoritas perawat klinik di unit rawat inap berumur 27,29 sampai 29 tahun. Hasil analisis terkait lama kerja, didapatkan nilai median masa kerja adalah 5 tahun. lama kerja tersingkat adalah 1 tahun dan terlama 13 tahun. Mayoritas perawat klinik di unit rawat inap memiliki masa kerja 4,46 sampai 5,67 tahun.

Implementasi komponen yang mendukung proses sistem jenjang karir tergambar pada tabel 1. Tabel 1 menunjukkan bahwa persepsi perawat terkait sistem jenjang karir berada pada median 2 (50\% dari nilai total) dengan nilai terendah 0 dan nilai tertinggi adalah 4 .

Tabel 2 menunjukkan mayoritas implementasi manajemen nyeri oleh perawat klinik setelah dilaksanakan jenjang karir selama 3 tahun mengalami peningkatan. Tabel 3 menunjukkan 
adanya hubungan yang bermakna antara variabel kredensial $(0,029)$ dan pengembangan professional $(0,017)$ berkelanjutan pada perawat klinik dengan implementasi manajemen nyeri yang dinilai dari dokumentasi keperawatan. Tabel 4 menunjukkan tidak adanya hubungan yang bermakna antara umur dan lama kerja perawat klinik dengan implementasi manajemen nyeri di unit rawat inap $(\mathrm{p}=0,149)$.

Tabel 5 menunjukkan adanya peningkatan rerata nilai implementasi manajemen nyeri antara sebelum dan sesudah implementasi sistem jenjang karir yaitu dari 3,91 menjadi 7,94. Analisis statistik menggunakan uji wilcoxon menghasilkan nilai probabilitas sebesar 0,0001 $(\mathrm{p}<0,05)$ yang menunjukkan adanya perbedaan implementasi manajemen nyeri yang bermakna antara sebelum dan sesudah implementasi sistem jenjang karir keperawatan di unit rawat inap, rumah sakit.

Berdasarkan analisis pemodelan akhir, maka variabel implementasi sistem jenjang karir yang paling berhubungan implementasi manajemen nyeri oleh perawat klinik adalah pengembangan profesional berkelanjutan.

Nilai $R$ square sebesar 0,041 , menunjukkan bahwa $4,1 \%$ dari variasi implementasi manajemen nyeri oleh perawat dapat dijelaskan oleh variabel pengembangan profesional berkelanjutan, sedangkan sisanya dijelaskan oleh variabel lainnya.

Tabel 1. Gambaran Implementasi Komponen Pendukung Sistem Jenjang Karir

\begin{tabular}{lccc}
\hline \multicolumn{1}{c}{ Variabel } & Median & Min. - Maks. & $95 \%$ CI \\
\hline Sistem Jenjang Karir & & & $1,72-2,32$ \\
a. Pemetaan sistem jenjang karir & 2 & $0-4$ & $2,78-3,67$ \\
b. Asesmen kompetensi & 3 & $0-14$ & $1,73-2,49$ \\
c. Kredensial & 1 & $0-5$ & $2,79-3,96$ \\
d. Pengembangan profesional berkelanjutan & 3 & $0-9$ & $0,65-0,97$ \\
e. Kewenangan klinis & 1 & $0-2$ & $3,92-4,73$ \\
Proses manajemen & 6 & $0-6$ & \\
\hline
\end{tabular}

Tabel 2. Gambaran Implementasi Manajemen Nyeri, Tahun 2013 dan 2015

\begin{tabular}{|c|c|c|c|}
\hline Variabel & Median & Min.-Maks. & $95 \% \mathrm{CI}$ \\
\hline $\begin{array}{l}\text { Pengkajian } \\
\text { a. } 2013 \\
\text { b. } 2015\end{array}$ & $\begin{array}{l}0 \\
5\end{array}$ & $\begin{array}{l}0-5 \\
0-5\end{array}$ & $\begin{array}{l}0,47-0,95 \\
1,95-4,05\end{array}$ \\
\hline $\begin{array}{l}\text { Intervensi } \\
\text { a. } 2013 \\
\text { b. } 2015\end{array}$ & $\begin{array}{l}0 \\
8\end{array}$ & $\begin{array}{l}0-8 \\
0-8\end{array}$ & $\begin{array}{l}2,24-3,42 \\
3,14-6,96\end{array}$ \\
\hline $\begin{array}{l}\text { Re asemen } \\
\text { a. } 2013 \\
\text { b. } 2015\end{array}$ & $\begin{array}{l}0 \\
1\end{array}$ & $\begin{array}{l}0-2 \\
0-2\end{array}$ & $0,44-1,24$ \\
\hline
\end{tabular}


Tabel 3. Hubungan Implementasi Sistem Jenjang Karir dengan Implementasi Manajemen Nyeri oleh Perawat klinik

\begin{tabular}{llcc}
\hline \multicolumn{1}{c}{ Variabel Independen } & Variabel Dependen & Nilai r & \\
\hline Sistem Jenjang Karir & & & 0,044 \\
a.Pemetaan & Implementasi Manajemen Nyeri & 0,692 \\
b. Asesmen kompetensi & Implementasi Manajemen Nyeri & 0,130 & 0,156 \\
c. Kredensial & Implementasi Manajemen Nyeri & 0,199 & $0,029^{*}$ \\
d.Pengembangan profesional berkelanjutan & Implementasi Manajemen Nyeri & 0,216 & $0,017^{*}$ \\
e. Kewenangan klinis & Implementasi Manajemen Nyeri & 0,167 & 0,067 \\
Kemampuan proses manajemen & Implementasi Manajemen Nyeri & 0,126 & 0,170 \\
\hline
\end{tabular}

Tabel 4. Hubungan Umur dan Lama Kerja Perawat klinik dengan Implementasi Manajemen Nyeri oleh Perawat klinik

\begin{tabular}{llcc}
\hline \multicolumn{1}{c}{ Variabel Confounding } & Variabel Dependen & Nilai r & $\mathrm{p}$ \\
\hline Umur & Implementasi Manajemen Nyeri & 0,148 & 0,104 \\
Lama kerja & Implementasi Manajemen Nyeri & $0,082 *$ & 0,374 \\
\hline
\end{tabular}

Tabel 5. Perbedaan Implementasi Manajemen Nyeri Antara Sebelum dan Sesudah Implementasi Sistem Jenjang Karir

\begin{tabular}{|c|c|c|c|c|c|c|c|}
\hline \multirow[t]{2}{*}{ Variabel } & \multicolumn{3}{|c|}{$\begin{array}{c}\text { Sebelum implementasi jenjang karir } \\
\text { (tahun 2013) }\end{array}$} & \multicolumn{3}{|c|}{$\begin{array}{l}\text { Sesudah implementasi jenjang karir } \\
\text { (tahun 2015) }\end{array}$} & \multirow[t]{2}{*}{$\mathrm{p}$} \\
\hline & Mean & SD & $95 \% \mathrm{CI}$ & Mean & SD & $95 \% \mathrm{CI}$ & \\
\hline $\begin{array}{l}\text { Implementasi } \\
\text { manajemen nyeri }\end{array}$ & 3,91 & 4,78 & $3,06-4,76$ & 7,94 & 6,043 & $6,85-9,03$ & 0,0001 \\
\hline
\end{tabular}

Tabel 6. Faktor Dominan yang Berhubungan Implementasi Sistem Jenjang Karir dengan Implementasi Manajemen Nyeri oleh Perawat klinik

\begin{tabular}{lcccc}
\hline \multicolumn{1}{c}{ Model } & Koefisien B & $\begin{array}{c}\text { Koefisien B } \\
\text { distandarisasi }\end{array}$ & $\mathrm{p}$ & R square $\left(\mathrm{R}^{2}\right)$ \\
\hline Konstanta & 9,297 & - & 0,000 & \\
$\begin{array}{l}\text { Pengembangan profesional } \\
\text { berkelanjutan }\end{array}$ & 0,375 & 0,202 & 0,027 & 0,041 \\
\hline
\end{tabular}

\section{Pembahasan}

Hasil penelitian menunjukkan bahwa karakteristik perawat tidak memiliki hubungan yang bermakna dengan implementasi manajemen nyeri di unit rawat inap. Hal ini didukung oleh
Abdullah, Sidin, dan Pasinringi (2014) dimana tidak ada hubungan yang signifikan antara karakteristik individu (umur, jenis kelamin, tingkat pendidikan dan masa kerja) dengan kinerja perawat pelaksana dalam pencegahan infeksi nosocomial. Namun hal ini tidak sejalan 
dengan Kumajas, Warouw, dan Bawotong (2014) yang menyimpulkan bahwa karakteristik individu yaitu umur, pendidikan, masa kerja dan status pernikah memiliki hubungan yang signifikan dengan kinerja perawat di RSUD Datoe Binangkang. Begitu pula Faura, Trilla, Lluch, Martinez, Canillas, dan Zabalegui (2014) menyatakan bahwa pendidikan dan lama kerja perawat di RS memengaruhi tingkat kemahiran dalam memberikan pelayanan pada pasien yang akan memengaruhi kualitas pelayanan itu sendiri.

Di rumah sakit, faktor usia menjadi salah satu pertimbangan pada proses rekrutmen calon karyawan, dengan harapan memiliki jiwa energik dan semangat tinggi serta menyukai tantangan baru namun tetap memegang prinsip dan nilai dasarnya. Begitu pula dengan faktor pendidikan yang menjadi pertimbangan dalam penempatan area kerja perawat baru (Any, Idris, Mukammala, \& Matindas, 2012).

Sistem jenjang karir di unit rawat inap RS telah dilaksanakan namun belum optimal. Proses rekrutmen dan seleksi perawat baru dilakukan melalui tes tulis dan wawancara pengetahuan keperawatan namun belum berfokus pada manajemen nyeri. Rahim (2015) menyatakan bahwa peningkatan perlindungan pada masyarakat pengguna layanan RS melalui proses identifikasi pengetahuan, keterampilan dan perilaku perawat.

Proses magang perawat baru, telah dilakukan bagi seluruh perawat baru namun tidak selama 1 tahun. Kim, Lee, Eudey, Lounsbury, dan Wede (2015) membandingkan pelaksanaan pre dan post program residensi selama 12-15 minggu pada 114 perawat di California memberikan dampak positif setelah pelaksanaan program.

Proses pemetaan perawat lama telah dilakukan, terbatas pada pendidikan keperawatan terakhir, pelatihan yang pernah diikuti, lama kerja, serta rekapitulasi profil perawat berdasarkan penjenjangan karir. Proses pemetaan level karir keperawatan didasarkan pada 3 jenjang yaitu junior nurse (junior nurse $1 \& 2$ ), senior nurse (senior nurse 1 \& 2), shift charge nurse. Shermont, Krepcio, dan Murphy (2009) menyatakan bahwa pemetaan karir perawat memberikan banyak keuntungan, tidak hanya bagi perawat tapi juga eksekutif keperawatan karena dapat memberikan semangat baru bagi perawat pelaksana, meningkatkan pengetahuan dan keterampilan melalui pengalaman yang dilalui, persiapan posisi sebagai pemimpin, perencanaan karir, serta pemberian kesempatan pengembangan karir internal dengan berpindah ke unit lain.

Jenjang Junior Nurse memiliki proporsi lebih banyak (68\%) dikarenakan perbandingan jumlah Shift Charge Nurse $(8,26 \%)$ yang lebih sedikit dari keseluruhan perawat di unit rawat inap rumah sakit. Tenaga keperawatan yang kompeten merupakan tanggung jawab utama bagi perawat manajer guna memastikan keselamatan pasien, kepuasan kerja perawat serta produktifitas. Peningkatkan jumlah registered nurse (RN) atau perawat teregistrasi merupakan strategi terbaik guna memberikan kualitas pelayanan yang tinggi (Young, Lee, Sands, \& McCombs, 2015).

Kualitas pelayanan pasien menjadi sangat baik jika didukung oleh meningkatnya jumlah perawat teregistrasi, peningkatan kualitas dibuktikan dengan menurunnya angka mortalitas, angka kejadian infeksi pada pasien, menurunnya lama masa rawat dan juga turunnya angka dirawat kembali atau readmission. Level perawat yang rendah memberikan pengaruh pada kesalahan pemberian obat dan juga tidak terlaksananya pemberian asuhan keperawatan (Griffith, et al., 2014).

Asesmen kompetensi bagi perawat klinik dilakukan secara berkala setiap 6 bulan bagi karyawan berstatus pegawai kontrak waktu tak tertentu. Setiap calon karyawan akan mengikuti masa pra kerja selamanya 2 tahun dan jika dianggap memenuhi standar profesi keperawatan akan ditempatkan pada jenjang sesuai hasil 
proses seleksi administrasi. Peningkatan jenjang karir dari junior nurse 1 ke 2 atau senior nurse 1 ke 2, dilakukan secara otomatis setelah mealui 2-3 tahun masa kerja. Sedangkan perawat yang akan meningkat dari jenjang junior nurse ke senior nurse atau senior nurse ke shift charge nurse harus melalui proses asesmen kompetensi, tes tulis, wawancara serta psikotes. Namun asesmen kompetensi terkait manajemen nyeri, belum tertuang dalam uraian tugas perawat klinik. Hal ini tidaksejalan dengan PPNI yang menetapkan bahwa salah satu kompetensi minimal perawat generalis adalah melakukan tanda-tanda vital dan pengkajian nyeri merupakan tanda vital kelima (Hariyati, 2014; Vadivelu, Mitra, Hines, Elia, \& Rosenquist, 2012). Kemenkes (2013) memperkuat bahwa proses asesmen kompetensi dapat dilakukan dengan mengajukan permohonan asesmen, melakukan asesmen mandiri, pra konsultasi hingga usulan banding.

Proses kredensial masih belum dilaksanakan karena belum memiliki komite keperawatan. Hal ini tergambar pada hasil penelitian, bahwa persepsi perawat tentang kredensial bera pada nilai 1 (rentang 0 - 5). Permenkes no.49 (2013) menyatakan bahwa kredensial merupakan proses pemastian kemampuan tenaga keperawatan sebelum diberikan kelayakan kewenangan klinis yang bertujuan untuk peningkatan kualitas dan proses pemberian pelayanan kesehatan. Needleman, Dittus, Pittman, Spetz, Newhouse (2014) mendukung bahwa kredesial memastikan dan memperjelas peran perawat serta anggota tim kesehatan lain. Kriteria hasil pelaksanaannya adalah peningkatan kompetensi dan performa perawat, peningkatan hasil kerja organisasi serta perbaikan struktur budaya organisasi, kepemimpinan dan iklim organisasi.

Kewenangan klinis merupakan komponen akhir dari system jenjang karir, yang menunjukkan nilai median 1 (rentang $0-2$ ). Implementasi di RS dilakukan dengan cara memberikan surat keputusan direktur sebagai bentuk pemberian kewenangan mengacu pada deskripsi kerja masing-masing jenjang. Hal ini tidak sejalan dengan AANA (2005) yang menyatakan bahwa kewenangan klinis merupakan pengakuan terhadap individu oleh suatu institusi dalam memberikan pelayanan pada pasien.

Kemenkes (2013) menyatakan bahwa pemberian kewenangan klinis tenaga keperawatan oleh direktur RS dilakukan melalui penerbitan surat penugasan klinis kepada perawat yang bersangkutan berdasarkan rekomendasi Komite Keperawatan. Buku putih merupakan salah satu dokumen yang berisi syarat-syarat yang harus dipenuhi tenaga keperawatan yang digunakan untuk menentukan kewenangan klinis.

Pemodelan akhir pada penelitian ini menyatakan bahwa Pengembangan Profesional Berkelanjutan yang merupakan bagian dari sistem jenjang karir memberikan pengaruh dalam pelaksanaan manajemen nyeri oleh perawat klinik. Hasil penelitian ini mendukung riset sebelumnya yang menyimpulkan bahwa jika PPB direncanakan dengan baik dapat berdampak pada peningkatan kompetensi dan keterampilan perawat (DeSilets \& Dickerson, 2010).

Program PPB terakreditasi yang diikuti oleh perawat dapat memperbaiki praktik keperawatan, PPB juga merupakan pembelajaran jangka panjang yang dapat meningkatkan kemampuan kritis perawat itu sendiri (Kemp \& Baker, 2013).

Staf perawat, sebanyak 200 orang, yang terlibat penelitian pada 2 RS dan 13 rumah perawatan menggambarkan bahwa persepsi positif dirasakan pada proses $C P D$ atau PPB. Selain itu, gaya kepemimpinan serta respon para manajer untuk melakukan perubahan juga memengaruhi pengembangan jenjang karir para perawat tersebut (Hughes, 2005; Staniland, Rosen, \& Wild, 2011).

Analisis kebutuhan pelatihan atau Training Needs Analysis (TNA) merupakan salah satu perencanaan yang dapat dilakukan secara lebih komprehensif dan pro-aktif dengan melihat 
kebutuhan pelayanan. Perawat manajer dan pimpinan pelayanan keperawatan bertanggung jawab dalam memperhitungkan anggaran biaya pelatihan (Staniland, 2011). PPB menjadi bagian yang tidak terpisahkan dalam implementasi jenjang karir dan dalam upaya meningkatkan kemampuan praktik keperawatan.

\section{Kesimpulan}

Jenjang karir keperawatan merupakan proses kehidupan dan pengembangan profesional keperawatan secara terus menerus. PPB merupakan variabel yang paling berhubungan dengan implementasi manajemen nyeri.

Pimpinan dan Manajemen Keperawatan disarankan untuk membuat analisis kebutuhan training sehingga pelaksanaan PPB sesuai dengan kebutuhan dan tujuan organisasi. Bagi staf perawat, diharapkan dapat membuat prioritas dalam pengembangan karirnya guna meningkatkan kompetensi dirinya, melibatkan diri dalam aktifitas coaching, pengembangan karir, mentoring, training internal serta proyek kerja keperawatan lainnya dan melakukan self assessment secara periodik guna perencanaan pengembangan karirnya (TN, HR, PN).

\section{Referensi}

Abdullah, K., Sidin, A.I., \& Pasinringi, S.A. (2014). Hubungan pengetahuan, motivasi, dan supervisi dengan kinerja pencegahan infeksi nosokomial di RSUD Haji Makassar (Tesis, Universitas Hasanudin). Diperoleh dari http://repository.unhas.ac.id/handle/1234567 $89 / 10571$

Any, K., Idris, R., Mukammalah, Z., Matindas, F. (2012). Satu dekade RSUD Cengkareng. Jakarta: RSUD Cengkareng.

DeSilets, L.D., \& Dickerson, P.S. (2010). Continuing nursing education: enhancing professional development. The Journal of Continuing Education in Nursing, 41 (3), 100-101. doi: 10.3928/00220124-2010022407.
Direktorat Bina Pelayanan Keperawatan. (2008). Pedoman indikator mutu pelayanan keperawatan klinik di sarana kesehatan. Jakarta: Direktorat Bina Pelayanan Keperawatan

Faura, T., Trilla, A., Lluch, T., Martinez, G., Canillas, L., \& Zabalegui, A. (2014). Nurse education, experience and the hospital context. Analysis of nurse expertise in a university hospital of catalonia (spain). American Journal of Nursing Research, 2 (3), 50-56. doi:10.12691/ajnr-2-3-4.

Griffith, P., Ball, J., Drennan, J., James, L., Jones, J., Saucedo, A.R., \& Simon, M. (2014). The association between patient safety outcomes and nurse/ healthcare assistant skill mix and staffing levels \& factors that may influence staffing requirements. Centre for Innovation and Leadership in Health Sciences: University of Southampton.

Hariyati, R.T.S. (2014). Perencanaan, pengembangan dan utilisasi tenaga keperawatan. Jakarta: PT Raja Grafindo Persada.

Hughes, E. (2005). Nurses' perceptions of continuing professional development. Nursing Standard, 19 (43), 41-49. Doi: 10.7748/ ns2005.07.19.43.41.c3904.

Kemp, S.J., \& Baker, M. (2013). Continuing professional development-reflections from nursing and education. Nurse Education in Practice, 13, 541-545. doi: 10.1016/ j.nepr.2013.04.009.

Kim, K.H., Lee, A.Y., Eudey, L., Lounsbury, K., \& Wede, P. (2015). New RN residency program to improve clinical competency, confidence, and socialization skills of novice nurses. Journal of Nursing Education and Practice, 5 (6). doi: https://doi.org/10.5430/jnep. v5n6p50

Kumajas, F.W., Warouw, H., Bawotong, J. (2014). Hubungan karakteristik individu dengan kinerja perawat di ruang rawat inap penyakit dalam RSUD Datoe binangkang kabupaten bolaang mongondow. Diakses dari ejournal.unsrat.ac.id pada 1 Juli 2015. 
Mantell, P., Hartwell, L. P., \& Branowicki, P. A. (2014). Development of an outcome measure to monitor the effectiveness of pain management. Clinical Journal of Oncology Nursing, 18 (1), 30-32. doi: 10.1188/14. CJON.30-32.

Montalvo, I. (2007). The national database of nursing quality indicators (NDNQI). The Online Journal of Issues in Nursing, A Scholarly Journal of the American Nurses Association, 12 (3). doi: 10.3912/OJIN. Vol12No03Man02

Needleman, J., Dittus, R. S., Pittman, P., Spetz, J., $\&$ Newhouse, R. (2014). Nurse credentialing research frameworks and perspectives for assessing a research agenda. USA: Institute of Medicine of the National Academies.

Ozlu, Z.K., \& Uzun, O. (2015). Evaluation of satisfaction with nursing care of patients hospitalaized in surgical clinics of different hospitals. International Journal of Caring Sciences, 8 (1), 19-24.

Rahim, M.B. (2015). E-portfolio indicator for competency assessment and virtual learning in malaysia skills certification. Diperoleh dari http://www.tvet-online.asia/issue4/rahim_tv et4.pdf
Shermont, H., Krepcio, D., Murphy, J.M. (2009). Career mapping developing nurse leaders, reinvigorating careers. Journal of Nursing Administration, 39 (10), 432-437.

Staniland, K, Rosen, L., \& Wild, J. (2011). Staff support in continuing profesional development. Nursing management, 18 (1), 33-37. doi: 10.7748/nm2011.04.18.1.33.c8414

Vadivelu, N., Mitra, S., Hines, R., Elia, M. \& Rosenquist, R. W. (2012). Acute pain in undergraduate medical education: an unfinished chapter. Pain Practice, 2 (8) $663-$ 671. doi: $10.1111 / \mathrm{j} .1533-2500.2012 .00580 . \mathrm{x}$

Young, L., Lee, M., Sands, L.P., \& McComb, S. (2015). Nursing activities and factors influential to nurse staffing decision-making. Journal of Hospital Administration, 4 (4). doi: 10.5430/jha.v4n4p24. 